\title{
REPRESENTASI MASKULINITAS BOYBAND SHINEE DALAM VIDEO KLIP RING DING DONG MELALUI ANANLISIS SEMIOTIKA
}

\author{
M. Adha Al Kodri, S.Sos., M.A
}

\begin{abstract}
Abstrack
In the ranks of K-pop industry, boyband group Shinee certainly not unfamiliar anymore. Since it was formed in 2008, they have received many awards in music's field. One of their single is championed tittled Ring Ding Dong was released digitally on October 14 th 2009.

In the video clip of Ring Ding Dong, described a collection of masculine men who dance vigorously. As well as body shape, accessories, and costume that they wear are very supports the actions of their masculine appearance. In other words, In other words, it can be said that the description of the man in the video clip leads to a masculine man with all the attributes of masculinity, but does not leave a gentle attitude, charisma and their prestige.

Therefore, if you see this, the important point in this research is to analyze the representations of masculinity in the video clip boyband Shinee Ring Ding Dong through analysis Semiotics. Semiotic models are models that researchers use semiotics of Roland Barthes. Barthes developed two levels of sign (staggered systems) which allows to generates also meanings stratified, namely the level of denotation and connotation.

Meanwhile, the results of this study indicate that masculinity is represented by the personnel of Shinee in the video clip Ring Ding Dong is manifold. Some of the scene showed a new concept of masculinity (the concept of "new man"), but some are still a traditional masculinity. When speaking of new concepts of masculinity, it can do a redefinition of the concept of masculinity, namely the concept of masculine brought by the image of the idol appeared in the mass media.
\end{abstract}

Keywords: Boyband Shinee, Masculinity, Semiotics.

\section{PENDAHULUAN}

\subsection{Latar Belakang Masalah}

Tahun 2011 dapat dikatakan sebagai puncak dari trend dunia musik Korea di Indonesia, atau lebih dikenal dengan istilah K-Pop. K-pop merupakan singkatan dari Korean Pop yang secara spesifik berkaitan dengan "Musik Pop Korea" (Korea Selatan). Trend K-Pop atau dikenal pula dengan istilah Demam Korea (Korean Wave) telah melanda berbagai negara diseluruh dunia, terutama di benua Asia. Trend budaya pop Korea ini menyebar ke seluruh penjuru dunia dan menjadi salah satu penyebab orang-orang di berbagai negara mempelajari bahasa dan kebudayaan Korea. Banyak artis dan kelompok musik K-Pop yang tergabung dalam boyband dan girlband yang popularitasnya sudah populer di mancaneg-

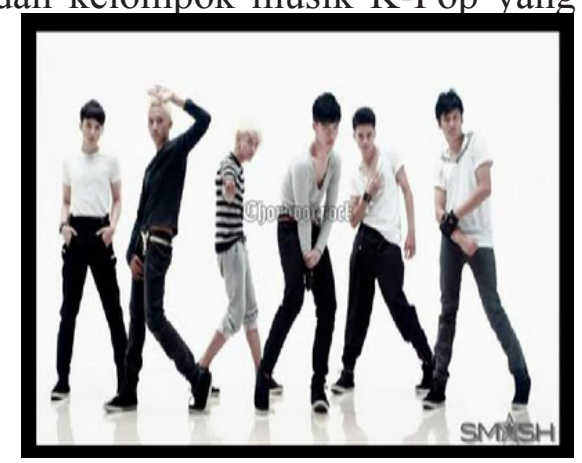


ara, termasuk di Indonesia.

Kini musik K-Pop tentunya telah menjadi fenomena yang sudah tidak asing lagi di telinga masyarakat. Bahkan virus K-pop inilah yang menjadi inspirasi menjamurnya pula grup boyband dan girlband di Indonesia. Seperti halnya Smash, Max5, Mr. Bee, NSG Star, S9B, XO-IX, 7 Icon, Cherry Belle, G-String, 5 Bidadari, dan masih banyak grup boyband dan girlband Indonesia lainnya.
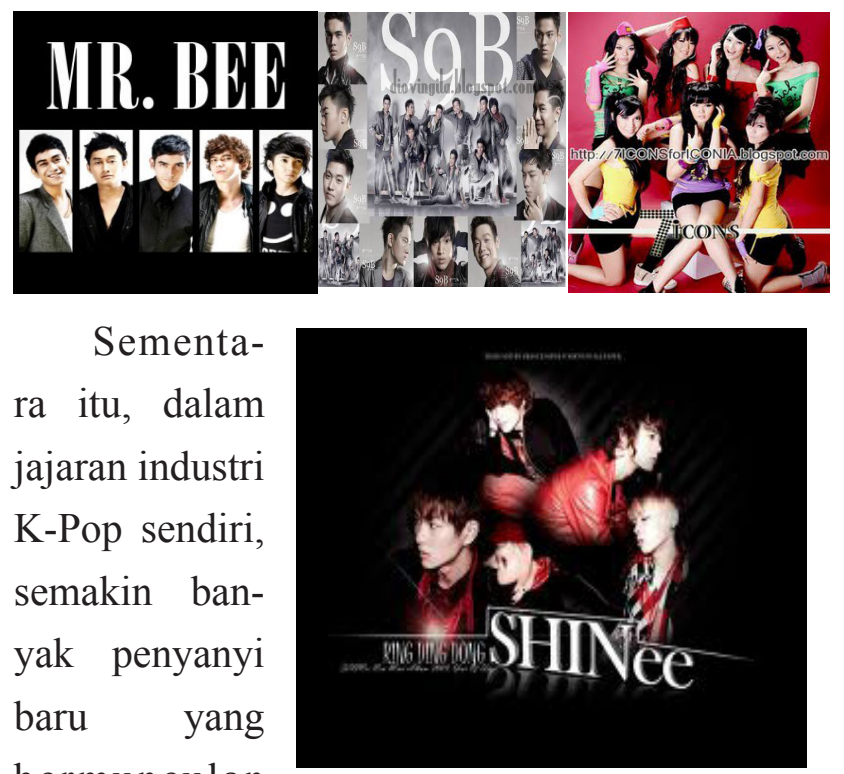

bermunculan

dan berhasil meraih ketenaran. Pembuktian dari kepopuleran mereka ialah banyaknya penghargaan di bidang musik yang telah diterima, salah satunya adalah boyband Shinee. Boyband Shinee dibentuk tahun 2008 dengan nama yang berasal dari kata shine dan ee yang mempunyai arti "menerima cahaya" atau menerima perhatian, siapa lagi jika bukan dari penikmat musik khususnya para penggemarnya. ${ }^{1}$ Boyband Shinee memiliki jumlah anggota 5 orang. Meraka adalah Lee Jinki, Kim Jonghyun, Kim Kibum, Choi Minho, dan Lee Taemin.

Lagu "Ring Ding Dong" merupakan track

1 Biodata Shinee - Foto Profil Personil Shinee Boyband Korea. Melalui http://www.erabaca.com/2012/04/biodata-shinee-foto-profil-personil.html. Diakses Pada Tanggal 6 Juli 2014, Pukul 13: 35 Wib. dan video klip dari mini album ke tiga mereka ditahun 2009 dengan nama album 2009 Year Of Us. Shinee merilis album mini ketiga mereka, 2009 Year Of Us pada 19 Okober 2009, tepatnya 5 bulan setelah mereka merilis album mini terakhir mereka. Singel yang dijagokan dari album mini ini adalah "Ring Ding Dong" yang dirilis secara digital pada tanggal 14 Oktober 2009. Comeback pertama mereka dilakukan pada tanggal 16 Oktober 2009 di acara KBS Music Bank. ${ }^{2}$ Pada video klip ini digambarkan sekumpulan pria yang sedang melakukan tarian dengan penuh semangat yang menunjukkan sisi kemaskulinan mereka yang ditampilkan dalam bentuk ekspresi, bentuk tubuh maupun aksesoris dan kostum yang mereka kenakan untuk menunjang penampilan maskulin mereka.

Penampilan tubuh yang atletis, pakaian yang modis dan unik dan terkadang tidak simetris, namun tidak meninggalkan sisi cantik dan lembut pada mayoritas penyanyi-penyanyi pria Korea membuat gambaran idola pria saat ini mengarah pada pria yang maskulin dengan segala atribut kemaskulinannya, namun tidak meninggalkan sikap lembut, kharisma, dan wibawa mereka. Penampilan maskulin sekaligus lembut dan cantik memang terkesan kompleks pada awal kemunculannya karena representasi pria maskulin yang berlaku dalam masyarakat pada umumnya adalah pria yang macho, pemberani, petualang, suka tantangan, dan tidak menunjukkan sisi lembut mereka. Seiring berjalannya waktu, hal yang dianggap tidak umum tersebut pada akhirnya menjadi hal yang biasa, sehingga pria yang maskulin sekaligus lembut dan cantik tidak menjadi sesuatu hal yang aneh lagi.

Sementara itu, representasi sendiri merupakan konsep yang digunakan dalam proses sosial

2 Shinee. Melalui http://id.wikipedia.org/wiki/Shinee. Diakses Pada Tanggal 6 Juli 2014, Pukul 14:47 Wib. 
pemaknaan melalui sistem penandaan yang tersedia, seperti dialog, tulisan, video, film, fotografi. Representasi adalah proses sosial dari 'representing'. Representasi menunjuk baik pada proses maupun produk dari pemaknaan suatu tanda. Representasi merujuk kepada konstruksi segala bentuk media (terutama media massa) terhadap segala aspek realitas atau kenyataan, seperti masyarakat, objek, peristiwa, hingga identitas budaya. Representasi ini bisa berbentuk kata-kata atau tulisan bahkan juga dapat dilihat dalam bentuk gambar bergerak. Stuart Hall kemudian menjelaskan bahwa :

"Representation is an essential part of the process by which meaning is produced and exchanged between member of a culture. It does involved the use of the language, of signs, and images which stands for or represent things. "3

Berdasarkan penjelasan tersebut, dapat dikatakan bahwa yang menjadi poin penting dalam tulisan ini adalah ingin melakukan analisis representasi maskulinitas boyband Shinee dalam video klip mereka yang berjudul Ring Ding Dong melalui analisis Semiotika.

\subsection{Rumusan Masalah}

Dari latar belakang yang telah disebutkan di atas, maka peneliti tertarik meneliti bagaimana maskulinitas boyband Shinee direpresentasikan dalam video klip Ring Ding Dong yang menampilkan sosok pria-pria tampan dan atletis sebagai penyanyi sekaligus model dalam video klip tersebut?

3 Iriany Cherry, 2011. Representasi Sensualitas Perempuan dalam Iklan Victoria Perfume Body Scent Versi "We Are The Star": Studi Semiotika Representasi Sensualitas dalam Iklan Victoria Perfume Body Scent Versi “We Are The Star. Hlm. 8.

\section{METODE PENELITIAN}

Penelitian yang digunakan dalam penelitian ini adalah penelitian yang menggunakan teknik analisis isi melalui pendekatan kualitatif yang bersifat eksplorasi. Analisis isi ini memungkinkan kita bisa menemukan dan mendokumentasikan ciri-ciri khusus dalam isi materi dalam jumlah besar yang jika tidak dilakukan akan tidak diperhatikan. ${ }^{4}$

Artinya, dalam melakukan penelitian ini peneliti mengamati dan mengidentifikasi setiap adegan-adegan yang dilakukan oleh personil Shinee dalam video klip Ring Ding Dong. Pengamatan dan pengidentifikasian ini tentunya bertujuan untuk menganalisis secara deskriptif mengenai representasi maskulinitas personil boyband Shinee dalam video klip Ring Ding Dong melalui analisis semiotika.

Sementara itu, analisis isi sendiri adalah teknik untuk menelaah isi atau informasi dan simbol yang terdapat dalam dokumen tertulis atau media komunikasi lain (misalnya, foto, film, lirik lagu, iklan). ${ }^{5}$

\section{PEMBAHASAN}

Semiotika merupakan ilmu yang mempelajari tentang tanda. Tanda-tanda tersebut menyampaikan suatu informasi sehingga bersifat komunikatif. Semiotika sendiri berasal dari kata Yunani, yakni semeion yang berarti tanda. Menurut Scholes, semiotika didefinisikan sebagai pengkajian tanda-tanda (the study of signs), pada dasarnya merupakan sebuah studi atas kode-kode, yaitu sistem apapun yang memungkinkan kita memandang entitas-entitas tertentu sebagai tanda-tanda atau sebagai sesuatu yang

\footnotetext{
4 Neuman, W. Lawrence, 2013. Metode Penelitian Sosial: Pendekatan Kualitatif dan Kuantitatif. Hlm. 57.

5 Neuman, W. Lawrence, 2013. Metode Penelitian Sosial: Pendekatan Kualitatif dan Kuantitatif. Hlm. 57.
} 
bermakna. ${ }^{6}$ Dengan kata lain, dapat dikatakan bahwa ada kecenderungan bahwa manusia selalu mencari arti atau berusaha memahami segala sesuatu yang ada di sekelilingnya dan dianggapnya sebagai tanda.

Dalam mengkaji representasi maskulinitas boyband Shinee dalam video klip mereka yang berjudul Ring Ding Dong ini, penulis akan menggunakan model semiotik dari Roland Barthes. Barthes mengembangkan dua tingkatan pertandaan (staggered systems) yang memungkinkan untuk dihasilkannya makna yang juga bertingkat-tingkat, yaitu tingkat denotasi (denotation) dan konotasi (connotation). ${ }^{7}$ Selain itu, Barthes juga melihat makna lebih dalam tingkatnya, tetapi lebih bersifat konvensional yaitu makna-makna yang berkaitan dengan mitos. Mitos dalam pemahaman semiotika Barthes adalah pengkodean makna dan nilai-nilai sosial sebagai sesuatu yang dianggap alamiah atau cerita yang digunakan suatu kebudayaan untuk menjelaskan atau memahami beberapa aspek dari realitas atau alam. ${ }^{8}$

\subsection{Konseps Maskulinitas}

Berbicara maskulin sama halnya jika berbicara mengenai feminim. Maskulin merupakan sebuah bentuk konstruksi kelelakian terhadap laki-laki. Carlyle menjelaskan bahwa maskulinitas berkaitan dengan kemadirian, kekuatan serta orientasi tindakan. ${ }^{9}$ Dengan kata lain, laki-laki tidak dilahirkan begitu saja dengan sifat maskulinnya secara alami, melainkan maskulinitas dibentuk oleh kebudayaan. Penyebaran konsep maskulini-

6 Kris Budiman, 2011. Semiotika Visual (Konsep, Isu, dan Problem Ikonisitas). Hlm. 3.

7 John Fiske, 2011. Cultural and Communication Studies : Sebuah Pengantar Paling Komprehensif. Hlm. 118.

8 John Fiske, 2011. Cultural and Communication Studies : Sebuah Pengantar Paling Komprehensif. Hlm.121.

9 Catherine Hall, 1992. White, Male, and Middleclass. tas inipun tidak dapat dipisahkan dari keberadaan media massa. Media, sebagai alat penyebar informasi, dapat menciptakan suatu imaji atau konsep dari sudut pandang tertentu tentang maskulinitas. Media massa turut berperan penting dalam membentuk konsep maskulinitas melalui pencitraan mengenai "kriteria ideal" untuk menjadi laki-laki yang maskulin atau macho.

Sementara itu, maskulinitas dalam masyarakat Korea saat ini terkonstruksi oleh elemen-elemen maskulinitas global, diantaranya maskulinitas bishonen Jepang, maskulinitas metroseksual Hollywood, serta maskulinitas tradisional Konfusius, Soenbi. Bishonen digambarkan sebagai lelaki yang tinggi, berwajah tirus dan feminim, berambut panjang atau bergelombang, serta memiliki senyum yang manis. ${ }^{10}$ Bishomen sendiri adalah karakter yang terdapat dalam komik untuk remaja putri (shojo manga) di Jepang. Di Korea, konsep inipun diaplikasikan dalam komik untuk remaja putri yang disebut dengan istilah konminam. Istilah tersebut merupakan perpaduan dari dua karakter yang berarti bunga dan pria tampan. ${ }^{11}$

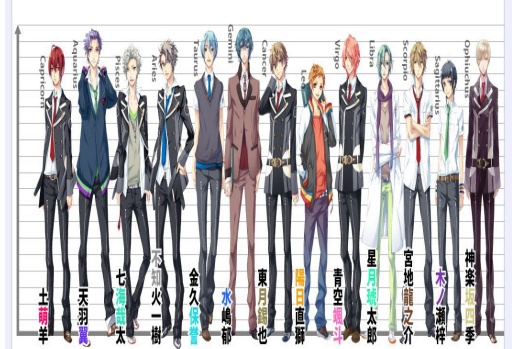

Bishonen Jepang (Shojo Manga)
Sementara itu, maskulinitas metroseksual merupakan kebudayaan populer Amerika. Dari beberapa kebudayaan populer di Hollywood, salah satu yang banyak diikuti adalah musik popnya. Selain mempelajari dan meniru cara menguasai panggung dari musik pop Hollywood, ar-

10 Sun Jung, 2011. Korean Masculinities and Transcultural Consumption: Yonsama, Rain, Oldboy, K-pop Idols. Hlm. 59.

11 Sun Jung, 2011. Korean Masculinities and Transcultural Consumption: Yonsama, Rain, Oldboy, K-pop Idols. Hlm. 58. 
tis-artis Korea pun banyak meniru cara membentuk tubuh bintang idola Hollywood. Salah satunya adalah pembentukan badan yang dapat kita lihat dalam so-

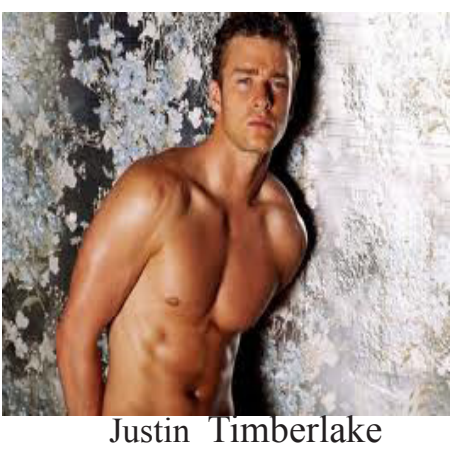
sok Justin Timberlake.

Justin memiliki tubuh yang berisi, berdada bidang, dan perut six packs. Penampilan fisik ini disebut dengan penampilan maskulinitas metroseksual. Metroseksual ini kemudian dapat kita artikan sebagai laki-laki yang berasal dari kalangan menengah atas, rajin berdandan, lebih mengagungkan fashion. Konsep maskulinitas baru ini menciptakan standar baru masyarakat bagi laki-laki. Dengan kata lain, dapat dikatakan bahwa semuanya membahas penciptaan imej baru bagi laki-laki, dimana karakter maskulinnya tidak lagi "segarang" dulu. Namun mereka lebih lembut dan trendi.

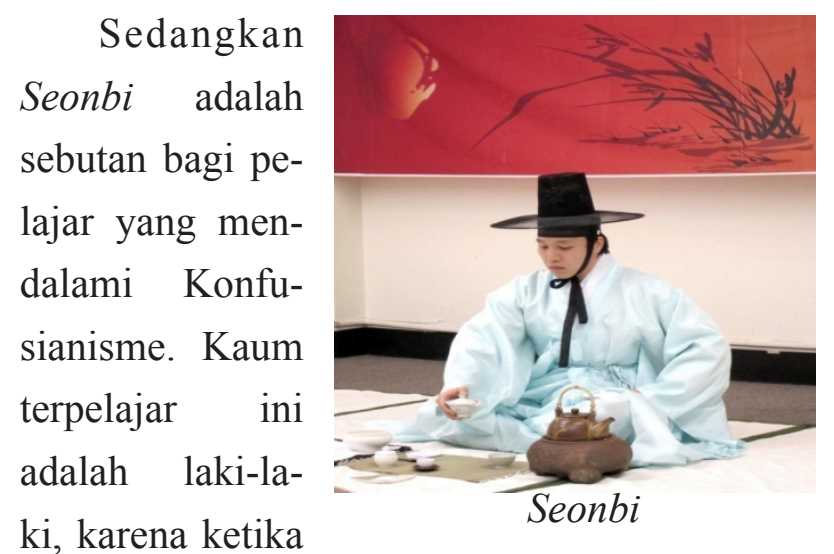
itu yang dapat menempuh pendidikan hanyalah kaum pria. Karakteristik maskulinitas ini terdapat pada masa dinasti Joseon, yang ketika itu lebih mengedepankan mental dibandingkan fisik. Oleh karenanya, terdapat beberapa karakteristik maskulinitas seonbi seperti sopan-santun dan lemah lembut yang masih dihargai oleh masyarakat Korea modern. ${ }^{12}$

12 Sun Jung. 2011. Korean Masculinities and Transcultural

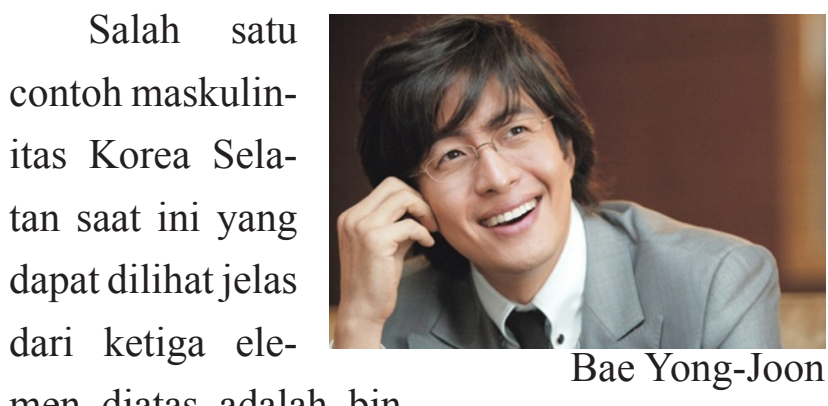
men diatas adalah bintang drama Winter Sonata yang direpresentasikan oleh Bae Yong-Joon. Maskulinitas Bae YongJoon merupakan perpaduan antara maskulinitas Konfusius yang lembut (wen), pria tampan Jepang (pretty boy-bishonen), dan metroseksual global.

\subsection{Analisis Semiotik Video Klip Shinee Ring Ding Dong \\ - Pakaian}

Gambar I

Pemakaian Busana Melewati Batasan Gender

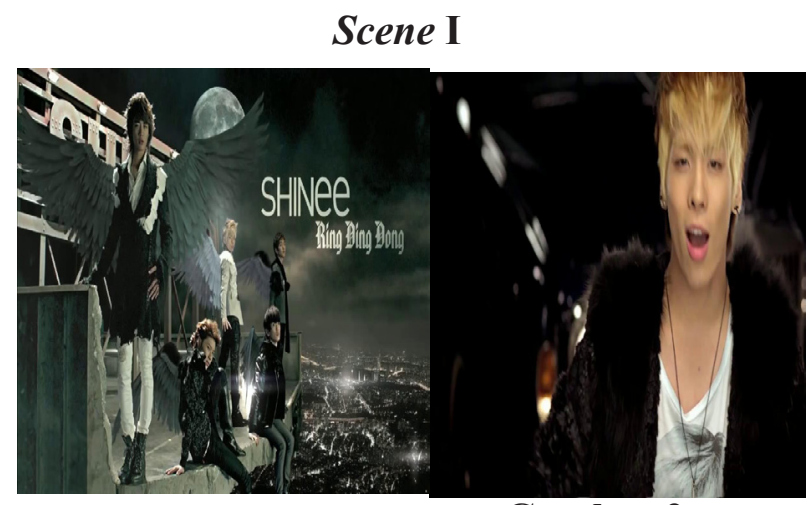

Gambar 1

Gambar 2

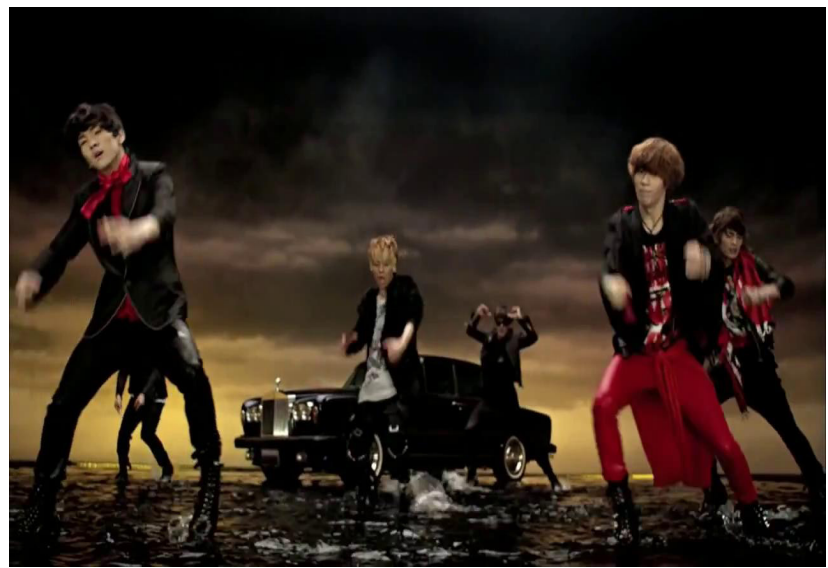

Gambar 3

Consumption: Yonsama, Rain, Oldboy, K-pop Idols. Hlm. 27. 
Tabel I. Penggambaran Scene I

\begin{tabular}{|c|l|}
\hline Gambar & \multicolumn{1}{|c|}{ Visual } \\
\hline $\mathbf{1}$ & $\begin{array}{l}\text { Personil Shinee mengenakan blazer } \\
\text { kulit bermotif bulu-bulu, dipadu } \\
\text { dengan celana panjang dan sayap } \\
\text { dibelakang. Tampak Choi Minho } \\
\text { memakai blazer hitam memanjang } \\
\text { sampai lutut dengan ujung } \\
\text { berumbai-rumbai. Blazer tersebut } \\
\text { bermotif bulu-bulu berwarna } \\
\text { putih. Gambar ini merupakan pose } \\
\text { diakhir video klip. }\end{array}$ \\
\hline $\mathbf{2}$ & $\begin{array}{l}\text { Kim Jonghyun sedang bernyanyi } \\
\text { dengan busana luaran blazer motif } \\
\text { bulu-bulu berwarna hitam dan } \\
\text { dalaman kaos bermotif yang bagian } \\
\text { dadanya sedikit turun. }\end{array}$ \\
\hline $\mathbf{3}$ & $\begin{array}{l}\text { Lee Taemin (depan sebelah kanan) } \\
\text { yang sedang bernyanyi dan menari } \\
\text { di lantai yang tergenang air dan } \\
\text { berlatar mobil menggunakan } \\
\text { busana luaran blazer hitam dengan } \\
\text { sedikit warna merah di bahu. } \\
\text { Sementara dalaman memakai } \\
\text { kaos bermotif dengan bawahan } \\
\text { celana ketat panjang berwarna } \\
\text { merah. Dibelakang celana tampak } \\
\text { kain merah memanjang kebawah. } \\
\text { Warna kainnya disamakan dengan } \\
\text { warna celana.. }\end{array}$ \\
\hline
\end{tabular}

Dengan mengenakan busana tersebut, kita dapat meihat bahwa mereka menunjukan gaya berpakaian seorang bintang. Dalam teori Barthes, hal tersebut dapat dilihat seperti di bawah ini:
Tabel II. Representasi Maskulinitas

Androgini ${ }^{13}$

\begin{tabular}{|c|c|c|c|}
\hline Mitos & Bahasa & $\begin{array}{l}\text { 1. Penanda } \\
\text { - Bajubermotif } \\
\text { dengan bagian } \\
\text { leher yang } \\
\text { rendah } \\
\text { - Celana } \\
\text { Panjang. } \\
\text { 3. Tanda } \\
\text { I. PENANDA } \\
\text { G a y a } \\
\text { be r pa k a i a n } \\
\text { metroseksual. } \\
\text { III. TANDA } \\
\text { Gaya busana } \\
\text { idola Korea } \\
\text { Selatan mele- } \\
\text { wati batas gen- } \\
\text { der maskulini- } \\
\text { tas-feminitas }\end{array}$ & $\begin{array}{l}\text { 2. Petanda } \\
\text { - G a y a } \\
\text { berpakaian } \\
\text { fem in i m- } \\
\text { maskulin. }\end{array}$ \\
\hline
\end{tabular}

Dari scene 1, dapat dilihat bahwa penampilan yang ditunjukkan oleh beberapa personil Shinee termasuk dalam karakteristik yang banyak diaplikasikan oleh para boyband di Asia, khususnya Korea Selatan. Mereka sering mengenakan kostum yang melewati batasan gender. Tak jarang mereka memakai baju berwarna merah muda, dan bahkan memakai celana ketat (gambar 3), bermotif-motif, serta berwarna-warni. Selain itu, pada scene 1 juga dapat dilihat dengan jelas bagaimana seluruh personil Shinee sangat menjaga penampilan tubuh dan gaya berbusana mereka. Mereka tanpa ragu mengenakan pakaian yang

13 Androgini adalah sebuah bentuk dimana batas-batas feminitas dan maskulinitas itu melebur atau tidak jelas. Berasal dari bahasa Yunani andro yang berarti pria dan gyn berarti wanita. 
umumnya akan dikenakan oleh seorang perempuan. Hal tersebut merupakan suatu keharusan dalam industri musik K-Pop saat ini. Hal ini tentunya sangat beralasan, karena seorang artis baik itu individu ataupun sebuah grup, jenis pakaian yang akan digunakan baik dalam panggung ataupun keseharian, ditentukan oleh pihak perusahaan tempat mereka bernaung. ${ }^{14}$ Ini dilakukan untuk mengangkat popularitas ataupun menjaga citra mereka sebagai artis idola.

Sementara itu penggunaan celana panjang oleh seluruh personil Shinee dianggap mampu mewakili sisi maskulinitas mereka. Tickner menjelaskan bahwa mungkin celana panjang menyatakan maskulinitas yang begitu kuat sehingga "dapat digunakan untuk menunjukkan kelelakian sebab celana panjang sudah teridentifikasi secara eksklusif'. ${ }^{15}$

\section{- $\quad$ Make Up}

\section{Gambar II}

\section{Penggunaan Make Up Oleh Personil Shinee}

\section{Scene II}

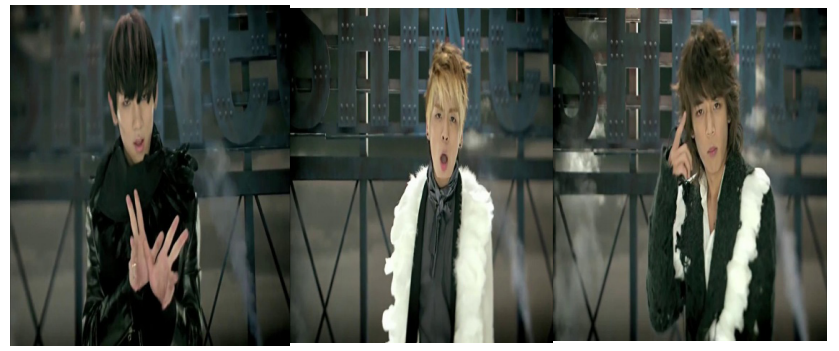

Gambar 1

Gambar 1

Gambar 1

Tabel III. Penggambaran Scene II

\begin{tabular}{|c|l|}
\hline Gambar & \multicolumn{1}{c|}{ Visual } \\
\hline $\mathbf{1}$ & $\begin{array}{l}\text { Kim Kibum yang mengenakan bedak } \\
\text { tipis, lipbalm, dan eye liner. }\end{array}$ \\
\hline
\end{tabular}

14 Heather A. Willoughby, 2006. Image is Everything: The Marketing of Feminity in South Korean Popular Music. Korean Pop Music: Riding the Wave. Hlm.101.

15 Dalam Malcolm Barnard, 2011. Fashion Sebagai Komunikasi. Hlm.123.

\begin{tabular}{|c|l|}
\hline $\mathbf{2}$ & $\begin{array}{l}\text { Nampak Kim Jonghyun sedang } \\
\text { bernyanyi. Terlihat jelas bibir itu } \\
\text { mengenakan lipbalm dan terdapat } \\
\text { bedak tipis pada wajahnya. }\end{array}$ \\
\hline $\mathbf{3}$ & $\begin{array}{l}\text { Choi Minho yang sedang bernyanyi } \\
\text { dengan mengangkat jari telunjuk } \\
\text { kearah kepala. Terlihat Choi Minho } \\
\text { menggunakan eye liner, lipbalm, dan } \\
\text { bedak tipis. }\end{array}$ \\
\hline
\end{tabular}

Umumnya, citra yang dibangun oleh idola Korea Selatan tersebut merupakan strategi perusahaan dalam memasarkan bintangnya. Bagi pihak perusahaan, citra tentunya merupakan faktor utama, sedangkan talenta dalam bermusik bisa menjadi nomor dua. Melalui pendekatan Barthes, maka hal ini dapat dilihat sebagai berikut:

Tabel IV. Representasi Maskulinitas Pembentuk Citra

\begin{tabular}{|c|c|c|c|}
\hline Mitos & Bahasa & $\begin{array}{l}\text { 1. Penanda } \\
\text { - Pakaian rapi } \\
\text { - Memakai } \\
\text { make up } \\
\text { wajah. } \\
\text { 3. Tanda } \\
\text { I. PENANDA } \\
\text { Penyanyi/artis } \\
\text { idola. } \\
\text { III. TANDA } \\
\text { Citra, faktor } \\
\text { utama bagi ar- } \\
\text { tis Korea. }\end{array}$ & $\begin{array}{l}\text { 2. Petanda } \\
\text { - Gaya } \\
\text { berpakaian } \\
\text { kelas } \\
\text { menengah atas } \\
\text { - Menjaga } \\
\text { penampilan. }\end{array}$ \\
\hline
\end{tabular}

Dari hal tersebut, dapat kita lihat bagaimana para artis idola sangat memperhatikan dan menjaga citranya. Mereka tidak ragu untuk mengenakan make up, meskipun hal itu umumnya dilakukan 
oleh wanita. Willoughby menjelaskan bahwa citra dalam trend musik K-Pop saat ini adalah kualitas yang paling esensial dari seorang penghibur, sementara talenta, musik dan kreatifitas memiliki peran sekunder. ${ }^{16}$ Karena adanya pemujaan terhadap ketampanan oleh para penggemarnya, hal ini memunculkan standar ketampanan tersendiri dalam industri ini. Di sisi lain dapat dijelaskan pula bahwa metamorfosis pria Korea Selatan dari macho hingga make up selama dekade terakhir atau lebih, sebagian besar dapat dijelaskan oleh persaingan sengit untuk pekerjaan, kemajuan dan asmara dalam suatu masyarakat di mana slogan populer mengatakan 'penampilan adalah kekuatan' ${ }^{17}$ Hal ini dapat pula dilihat banyaknya iklaniklan kosmetik di Korea Selatan yang menggunakan pria sebagai model iklan mereka.

\section{- $\quad$ Ekspresi}

\section{Gambar III}

\section{Ekspresi Sedih dan Cemberut Personil Shinee}

\section{Scene III}

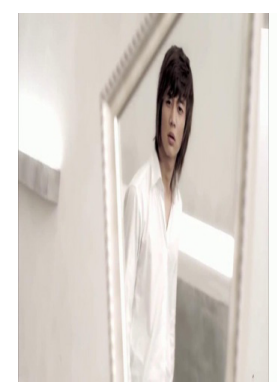

Gambar 1

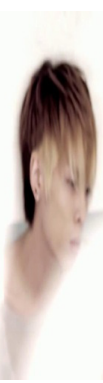

Gambar 2

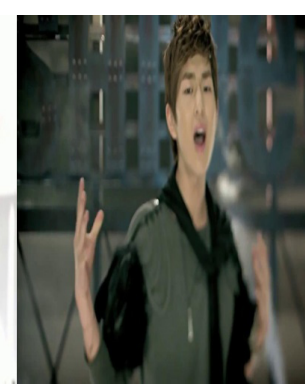

Gambar 3

16 Heather A. Willoughby, 2006. Image is Everything: The Marketing of Feminity in South Korean Popular Music. Korean Pop Music: Riding the Wave. Hlm. 102.

17 Adrian Marnoto, 2012. Pria Korea Paling Suka Bersolek dari Pria Lain di Dunia. Melalui http://www. menjelma.com/2012/09/foto-pria-koreapaling-suka-bersolek.html. Diakses Pada Tanggal 5 Juli 2014, Pukul 22:30 Wib.

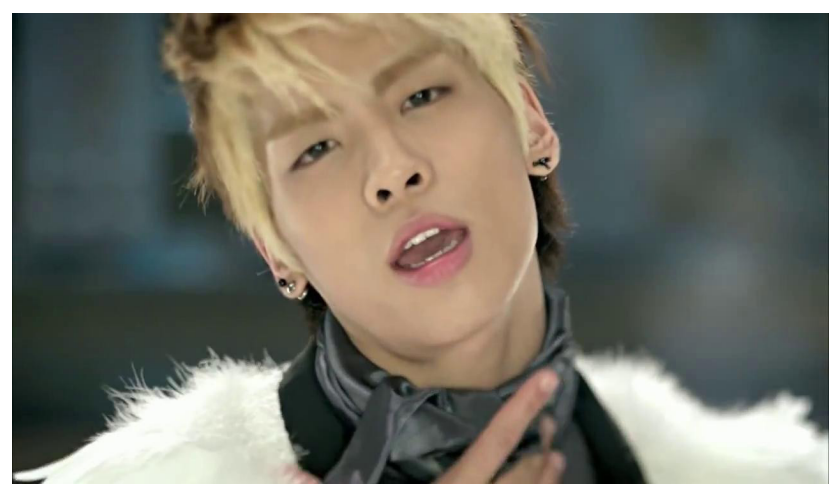

Gambar 4

Tabel V. Penggambaran Scene III

\begin{tabular}{|c|l|}
\hline Gambar & \multicolumn{1}{|c|}{ Visual } \\
\hline $\mathbf{1}$ & $\begin{array}{l}\text { Choi Minho yang menatap kearah } \\
\text { kamera melalui cermin. Nampak } \\
\text { kesedihan yang terpancar dari tatapan } \\
\text { matanya. }\end{array}$ \\
\hline $\mathbf{2}$ & $\begin{array}{l}\text { Kim Jonghyun yang sedang } \\
\text { menunjukkan ekspresi sedih. }\end{array}$ \\
\hline $\mathbf{3}$ & $\begin{array}{l}\text { Lee Jinki sedang menyanyi, sambil } \\
\text { menatap kearah kamera dengan } \\
\text { ekspresi wajah sedih. }\end{array}$ \\
\hline $\mathbf{4}$ & $\begin{array}{l}\text { Kim Jonghyun yang sedang menyanyi } \\
\text { dan memandang sedih kearah kamera } \\
\text { dengan tangan di dadanya. }\end{array}$ \\
\hline
\end{tabular}

Dalam scene III tersebut, dapat kita lihat, bagaimana personil Shinee tanpa ragu dan malu-malu menunjukkan ekspresi sedih mereka. Melalui pendekatan Barthes, maka hal tersebut dapat kita lihat sebagai berikut: 
Tabel VI. Representasi Maskulinitas Sensitif

\begin{tabular}{|c|c|c|c|}
\hline Mitos & Bahasa & $\begin{array}{l}\text { 1. Penanda } \\
\text { - Ekspresi } \\
\text { muka sedih } \\
\text { dan cemberut } \\
\text { 3. Tanda } \\
\text { I. PENANDA } \\
\text { B e b e r a p a } \\
\text { p e r s o n i } 1 \\
\mathrm{~S} \text { h i n e e } \\
\text { bersedih dan } \\
\text { cemberut } \\
\text { III. TANDA } \\
\text { Berekspresi } \\
\text { sedih merupa- } \\
\text { kan salah satu } \\
\text { karakter pria } \\
\text { yang cend- } \\
\text { erung lembut } \\
\text { dan sensitif }\end{array}$ & $\begin{array}{l}\text { II. PETANDA } \\
\text { B e b e r a p a } \\
\text { p e r s o n i } 1 \\
\text { S h i n e e } \\
\text { menunjukkan } \\
\text { kerapuhannya }\end{array}$ \\
\hline
\end{tabular}

Umumnya, karakteristik maskulin yang diketahui masyarakat adalah seorang pria yang "keras atau kasar", berjiwa kompetitif, menahan perasaan dan bersikap dingin. Namun, karena budaya dan periode waktu, maka karakteristik itupun berubah. Saat ini, maskulinitas sangat terkonstruksi oleh media massa. Media sangat berperan penting dalam membentuk konsep maskulinitas melalui pencitraan mengenai "kriteria ideal" untuk menjadi laki-laki yang maskulin atau macho.

Seperti pada scene III, beberapa personil Shinee merepresentasikan maskulinitas "lemah lembut" dan "sensitif". Jung (2011) menjelaskan bahwa maskulinitas ini merupakan salah satu karakter dalam ideologi Konfusius, yakni seorang lelaki ideal adalah seorang lelaki yang lemah lembut tetapi berkeinginan kuat. Maskulinitas dalam scene III merupakan tipikal dalam maskulinitas soenbi yang terpengaruh oleh Konfusius yang masih dipegang hingga saat ini. Jika seorang pria dapat menunjukkan kelemah lembutan dan sensitifitas, maka hal tersebut menunjukkan bahwa ia merupakan pria yang berbudaya.

\section{PENUTUP}

Semiotika merupakan ilmu yang mempelajari struktur, jenis, tipologi, serta relasi-relasi tanda dalam penggunaannya di dalam masyarakat. Oleh sebab itu, semiotika mempelajari relasi diantara komponen-komponen tersebut dengan masyarakat penggunanya. Semiotika juga melihat suatu simbol sebagai sesuatu yang sangat terbuka sehingga sangat mungkin menghasilkan beragam interpretasi. Dengan demikian interpretasi peneliti mengenai maskulinitas para personil Shinee dalam video klip Ring Ding Dong ini dapat disimpulkan bahwa Shinee merepresentasikan citra pria yang sedemikian rupa sebagai artis idola. Gaya berbusana mereka dikontrol oleh manajemen. Hal ini merupakan bagian dari strategi pemasaran bagi artis-artisnya agar selalu diingat dan terus diidolakan para penggemarnya.

Para personil Shinee juga tidak hanya menjual suara ataupun talentanya dalam bermusik, tetapi juga memasarkan citranya. Kemudian, maskulinitas yang direpresentasikan oleh personil Shinee tersebut melalui video klip Ring Ding Dong ini juga bermacam-macam. Beberapa scene menunjukkan adanya konsep maskulinitas baru (konsep "pria baru”), namun sebagian juga masih merupakan maskulinitas tradisional. Ini membuktikan bahwa maskulinitas yang dihadirkan dalam video klip Ring Ding Dong ini merupakan komoditi dalam industri hiburan Korea Selatan. Dengan demikian, dapat dikatakan pula 
bahwa telah terjadi pendefinisian ulang terhadap konsep maskulinitas. Kini, maskulinitas yang berusaha untuk diyakini adalah maskulin yang dibawa oleh citra dari para aris idola yang selalu tampil di media massa.

\section{Daftar Pustaka}

\section{Sumber Buku:}

Barnard, Malcolm, 2011. Fashion Sebagai Komunikasi. Yogyakarta: Jalasutra.

Budiman, Kris, 2011. Semiotika Visual (Konsep, Isu, dan Problem Ikonisitas). Yogyakarta: Jalasutra.

Cherry, Iriany, 2011. Representasi Sensualitas Perempuan dalam Iklan Victoria Perfume Body Scent Versi “We Are The Star": Studi Semiotika Representasi Sensualitas dalam Iklan Victoria Perfume Body Scent Versi "We Are The Star. Program Studi Ilmu Komunikasi FISIP UPN "Veteran” Jawa Timur.

Fiske, John, 2011. Cultural and Communication Studies : Sebuah Pengantar Paling Komprehensif. Yogyakarta: Jalasutra.

Hall, Catherine, 1992. White, Male, and Middleclass. Cambridge: Polity Press.

Jung, Sun, 2011. Korean Masculinities and Transcultural Consumption: Yonsama, Rain, Oldboy, K-pop Idols. Hong Kong: Hong Kong University Press.

Neuman, W. Lawrence, 2013. Metodologi Penelitian Sosial: Pendekatan Kualitatif dan Kuatitatif. Jakarta: PT Indeks.

Willoughby, Heather A., 2006. Image is Everything: The Marketing of Feminity in South Korean Popular Music. Korean Pop Music: Riding the Wave. Ed. Keith Howard. Kent, UK: Global Oriental.

\section{Sumber Internet:}

Biodata Shinee - Foto Profil Personil Shinee Boyband Korea. Melalui http://www.erabaca.com/2012/04/biodata-shinee-foto-profil-personil.html. Diakses Pada Tanggal 6 Juli 2014, Pukul 13: 35 Wib.

Marnoto, Adrian. 2012. Pria Korea Paling Suka Bersolek dari Pria Lain di Dunia. Melalui http://www.menjelma.com/2012/09/foto-pria-koreapaling-suka-bersolek.html. Diakses Pada Tanggal 5 Juli 2014, Pukul 22:30 Wib.

Shinee. Melalui http://id.wikipedia.org/wiki/ Shinee. Diakses Pada Tanggal 6 Juli 2014, Pukul 14:47 Wib.

Video Klip Shinee Ring Ding Dong, melalui http:// www.youtube.com/watch?v=roughtzsCDI. Diakases Pada Tangal 3 Juli 2014, Pukul 14:19 Wib. 